\title{
DIREITO E POLÍTICA: \\ o Ministério Público e a defesa dos direitos coletivos
}

\section{Rogério Bastos Arantes}

\section{Introdução}

\author{
0 risoo que 0 Ministério Públioo oferece \\ é 0 riso de fazer œm que a lei seja amprida. \\ (Promotor de justiça de São Paulo)
}

O Ministério Público brasileiro está passando por um importante processo de reconstrução institucional que, associado à normatização de direitos coletivos e à emergência de novos instrumentos processuais, tem resultado no alargamento do acesso à Justiça no Brasil e, em especial, na canalização de conflitos coletivos para 0 âmbito judicial. O Ministério Público tem sido o agente mais importante da defesa de direitos coletivos pela via judicial e, dado que os conflitos relativos a tais direitos têm geralmente conotação política, pode-se dizer que também tem impulsionado um processo mais amplo de judicializaçao de onflitos políticos e, no sentido inverso, de politização do sistema judicial.

Esse duplo movimento de judicialização/ politização tem balizamentos jurídicos e políticos. Do ponto de vista legislativo, desde pelo menos o início dos anos 80 , temos assistido a um importante processo de normatização de direitos que, em função de sua natureza difusa e/ ou coletiva, encontravam-se até então excluídos do ordenamento jurídico brasileiro. Refiro-me especialmente a áreas como meio ambiente, patrimônio histórico e cultural e direitos do consumidor, num primeiro momento. Em seguida, essa normatização ampliou-se em direção ao patrimônio público e ao controle da probidade administrativa, até chegar aos serviços de relevância pública que envolvem direitos fundamentais como saúde, educação, trabalho, segurança, lazer etc. 0 instrumento capaz de ensejar a defesa judicial de tais interesses e direitos - a ação civil pública - teve sua existência legal regulamentada em 1985.

Do ponto de vista político, a redemocratização do país produziu forte impacto sobre o sistema de justiça. De um lado, a demanda por justiça, em grande parte represada nos anos de autoritarismo, inundou o Poder Judiciário com o fim dos constrangimentos impostos pelo regime militar ao seu livre funcionamento. De outro, a democratização e 0 retorno ao Estado de direito recolocaram a necessidade de juízes e árbitros legítimos para decidir eventuais conflitos entre sociedade e governo e entre os poderes do próprio Estado. Este papel foi atribuído em grande medida ao Poder Judiciário. 
A Constituição de 1988 representa um marco jurídico e político desse processo. Ela consolidou em norma fundamental mudanças legislativas anteriores, na área dos direitos difusos e coletivos, além de fornecer as bases para a ampliação da codificação de novos direitos transindividuais. Ela também arremessou as instituições judiciais à esfera política quando ampliou as formas de controle judicial da constitucionalidade de atos normativos do Executivo e de leis do Parlamento. ${ }^{1}$ Foi além nesse sentido quando retirou o Ministério Público da alçada do Poder Executivo, conferindo-lhe autonomia administrativa e independência funcional, deslocando-o da tarefa de defender o Estado para a condição de fiscal e guardião dos direitos da sociedade.

Além desses balizamentos jurídicos e políticos, o movimento de judicialização/ politização tem fortes traços de voluntarismo político. Refiro-me aos integrantes do Ministério Público. A observação da atuação do Ministério revela que setores dentro da instituição têm se dedicado enfaticamente à sua transformação em instrumento de luta pela construção da cidadania.

Estas são, em linhas gerais, as questões que abordarei neste texto. Para tanto, na primeira parte, analiso as mudanças institucionais recentes que possibilitaram a constituição dessa nova arena judicial de solução de conflitos, tendo em vista três aspectos: a normatização dos chamados direitos difusos e coletivos, o novo papel do Ministério Público nessa área, e o instrumento de defesa desses direitos - a ação civil pública. Na segunda parte, com base em alguns resultados de pesquisa empírica, procuro explorar a visão dos próprios membros da instituição sobre os limites e possibilidades da consolidação de um novo papel institucional do Ministério Público. Como se trata de um tema novo e pouco explorado pelas ciências sociais, a parte final do texto mais sugere questões para reflexão futura do que oferece respostas conclusivas.

\section{Quadro institucional: direitos difusos e coletivos, ação civil pública e o papel do Ministério Público}

Dentre as instituições que compõem o sistema de justiça no Brasil, sempre coube ao Ministério
Público (MP) duas funções principais: (a) a de fiscal da lei (custos legis) e (b) a de titular da ação penal pública. Como fiscal da lei, o MP deve acompanhar a aplicação da lei pelo juiz em casos concretos envolvendo direitos individuais considerados indisponíveis, relacionados geralmente a áreas de família, registro e filiação, sucessões, defesa dos incapazes etc. Nesses casos, o MP não é parte no processo, mas figura como órgão interveniente. Constitui-se em um terceiro elemento, ao lado do juiz e das partes em conflito, representando 0 Estado e sua função pública de zelar por direitos indisponíveis e interesses de indivíduos classificados juridicamente como incapazes. Como titular da ação penal pública, o MP está encarregado de acionar o Poder Judiciário em nome do Estado com vistas à aplicação da pena nos crimes codificados pela legislação. 0 direito de punir é exclusividade do Estado e o MP é o órgão estatal que detém a responsabilidade exclusiva de desenvolver a acusação no processo criminal. Apenas de modo subsidiário a vítima ou seu representante podem atuar neste tipo de processo judicial. ${ }^{2}$

Mediante mudanças legislativas, ao longo das duas últimas décadas o MP veio acumulando novas e importantes atribuições, dentre as quais se destaca a promoção da ação civil pública. Por intermédio desse instrumento, o MP tem a possibilidade de acionar o Poder Judiciário para promover a defesa de direitos transindividuais, recentemente instituídos por lei e mais conhecidos como direitos difusos e coletivos.

A Sociologia Jurídica tem dedicado amplo espaço à discussão desses novos direitos. De uma forma geral, o debate jurídico tem enfatizado não só a novidade da normatização legal e constitucional desses direitos, mas também o fato de representarem uma nova categoria dentro do ordenamento jurídico tradicional, de matriz liberal e princípios de organização essencialmente individualistas. ${ }^{3}$

$\mathrm{Na}$ verdade, mais do que uma renovação de atribuições do MP, pode-se dizer que nestas duas últimas décadas constituiu-se no Brasil uma nova arena judicial de solução de conflitos que até então não tinham acesso ao sistema de justiça.

Embora, no debate jurídico, seja comum identificar a Constituição de 1988 como marco inicial da 
mudança do papel institucional do MP e da normatização dos direitos difusos e coletivos, uma análise de textos legais anteriores é capaz de demonstrar que a nova Constituição apenas consolidou em norma fundamental o que já vinha sendo instituído, através de leis ordinárias e complementares, nas esferas federal e estadual.

Nesse sentido, a Lei $\mathrm{n}^{0}$ 6938, que instituiu a Política Nacional do Meio Ambiente em 1981, pode ser considerada 0 marco jurídico inicial da normatização de interesses difusos e coletivos no Brasil e também da inclusão de novos instrumentos processuais, em especial a legitimidade do MP para proposição de ação de responsabilidade civil e criminal por danos causados ao meio ambiente (art. 14, §10). Pouco tempo depois, a Lei Complementar $n^{0} 40$, de 14 de dezembro de 1981, que deu nova organização nacional ao Ministério Público, definiu como uma de suas funções institucionais "promover a ação civil pública, nos termos da lei" (art. 3, III). Em concordância com a Lei Orgânica Nacional, a Lei Orgânica do MP do Estado de São Paulo, no ano seguinte, também fez referência à ação civil pública como um de seus instrumentos de atuação. Até então, entretanto, não havia regulamentação legislativa específica para esse novo instrumento processual. Somente em 1985, quatro anos após sua primeira aparição em textos legais, é que uma lei específica veio regulamentar com precisão esse novo tipo de ação - que aqueles textos apenas tangenciaram - , definindo seu objeto, o foro competente, a legitimação para utilizá-la, as atribuições do Ministério Público etc. ${ }^{4}$

É interessante notar, portanto, que a ação civil pública "preexistiu" ao texto de 1985, que a regulamentou. Sem dúvida, trata-se de uma forma peculiar de evolução do direito, em que leis versando sobre assuntos específicos, por exemplo, o meio ambiente, ou textos de caráter institucional como as leis orgânicas do MP vão engendrando um novo mecanismo processual. No caso da lei sobre meio ambiente, o mecanismo aparece como forma nova, melhor adaptada à tutela de um tipo novo de interesse, que por ser difuso não encontra na organização tradicional do processo judicial meio adequado à sua defesa. No caso da lei orgânica do MP, é a própria instituição que, ao se reorganizar, inscreve entre as suas funções principais a proposição da ação civil pública, que só seria criada por lei própria três anos mais tarde. Há fortes indícios, portanto, de uma evolução legislativa e processual baseada na estratégia "dois passos para frente, nenhum para trás", ou seja, leis que instituem direitos ou regulam atribuições de uma organização no mesmo ato lançam as bases para um aperfeiçoamento posterior. A respeito desse processo, que culminou com a Lei da Ação Civil Pública, disse um dos promotores ${ }^{5}$ entrevistados:

Eu acho que você pode determinar a Lei 6938 , de 1981, que foi a lei que instituiu a Política Nacional do Meio Ambiente, como marco inicial da atuação do MP nessa área.[...] Então, a partir daí, o Promotor passou a funcionar como defensor do interesse coletivo, mas ainda sem um instrumento processual próprio. Ações pioneiras (como o derramamento de óleo em Bertioga em 1983, Vila Socó e outras) revelaram a necessidade de haver um rito processual próprio, uma ação específica para tutelar esses interesses, e aí houve uma série de estudos e até um movimento de lobby que levou à criação e edição da Lei 7347 , de 1985, que foi a lei que criou a ação civil pública. $\mathrm{E}$ isso tudo num contex to histórico da época da liberalização do regime, da abertura política. Então havia aquela avidez pela cidadania, pela partiapação, tudo aquilo que estava reprimido pelo regime autoritário, participar da discussão dos assuntos de interesse público [...] (Promotor 1; grifo meu)

A ação civil pública não é novidade somente do ponto de vista do objeto que visa defender. Outras peculiaridades, que descreverei a seguir, reservam-lhe lugar especial no conjunto das ações codificadas no direito brasileiro.

A Lei $n^{0} 7347 / 85$ disciplinou a ação civil pública de responsabilidade por danos causados ao meio ambiente, ao consumidor, a bens e direitos de valor artístico, estético, histórico, turístico e paisagístico. ${ }^{6}$ Visando à proteção desses direitos e interesses, a lei definiu como objeto da ação "a condenação em dinheiro ou o cumprimento de obrigação de fazer ou não fazer". Por obrigacão de fazer ou não fazer deve-se entender a sentença judicial que 
obriga o réu a reparar o dano causado, ou suspender eventual atividade que esteja violando tais direitos coletivos ou que simplesmente esteja pondo-os em risco. Embora a maioria das sentenças inclua a condenação em dinheiro por danos causados, o entendimento predominante na jurisprudência e na doutrina tem sido o de que a obrigação de fazer ou não fazer deve ser privilegiada na decisão judicial. Isto tem conferido um caráter essencialmente prático às sentenças judiciais em ações civis públicas, sob a justificativa de que o interesse principal nesse caso é a reparação concreta e imediata do dano causado ao meio ambiente, ao patrimônio histórico e cultural e aos consumidores.

No caso da condenação em dinheiro, a Lei $\mathrm{n}^{0}$ 7347/ 85 prevê a criação de um fundo para 0 qual serão revertidas as indenizações, "sendo seus recursos destinados à reconstituição dos bens lesados". Isto se dá porque uma das características dos direitos difusos é justamente a sua indivisibilidade. Não há como dividir, por exemplo, a indenização paga por uma indústria que derramou produtos tóxicos no leito de um rio. A ação foi movida contra a empresa em nome de toda a coletividade. 0 resultado, da mesma forma, deve ser revertido em benefício de todos. Daí a existência do fundo, a ser gerido por um Conselho Federal e Conselhos Estaduais, encarregados de aplicar os recursos na reparação dos danos. ${ }^{7}$

A promoção da ação civil pública perante 0 Judiciário não é monopólio do Ministério Público. União, estados e municípios, autarquias, empresas públicas, fundações e sociedades de economia mista também estão legitimados a fazer uso dela. Além destes, a Lei $\mathrm{n}^{0}$ 7347/ 85 confere legitimidade a associações que estejam constituídas há pelo menos um ano e que incluam, entre suas finalidades institucionais, a proteção ao meio ambiente, ao consumidor e/ ou ao patrimônio histórico e cultural (art. 5). Tal legitimação, conhecida como conoorrente, visou democratizar o uso do novo instrumento, permitindo a defesa dos interesses coletivos por agentes públicos estatais e da sociedade civil. Entretanto, a experiência recente tem demonstrado que União, estados e municípios têm se apresentado mais no banco dos réus e menos na condição de autores das ações. De outro lado, as associações civis têm apresentado uma performanœe bastante tímida até agora, talvez por desconhecimento ou mesmo por falta de condições adequadas à utilização eficaz desse tipo de instrumento judicial. Aparentemente, é o Ministério Público quem mais tem se destacado no uso da ação civil pública, em todas as áreas dos direitos difusos e coletivos. ${ }^{8}$

O utra inovação importante da Lei $\mathrm{n}^{0} 7347 / 85$ é a instituição da responsabilidade objetiva, pouco comum no direito brasileiro. Juridicamente, a responsabilidade objetiva torna desnecessária a demonstração do elemento subjetivo presente no ato lesivo ao interesse difuso ou coletivo. Isto é, basta que seja comprovada a relação de causalidade entre a ação e 0 dano para que 0 réu seja condenado a repará-lo, sem que se precise demonstrar a existência subjetiva da culpa. ${ }^{9}$ A Lei $n^{0}$ 7347/ 85 prevê ainda a inversão do ônus da prova (cabe ao réu provar que não incorreu em erro) e a irrelevância da licitude da atividade (o responsável terá que responder por danos causados a direitos coletivos, mesmo que sua atividade conte com a aprovação dos órgãos públicos competentes).

Finalizando, a Lei $n^{0} 7347 / 85$ também reserva novidade em relação ao papel dos magistrados. Freqüentemente, os danos causados ao meio ambiente, ao consumidor e ao patrimônio histórico e cultural não podem esperar o ritmo lento dos julgamentos, imposto pelas regras processuais desatualizadas dos códigos brasileiros. Assim, a Lei da Ação Civil Pública permite ao juiz, dentre outras coisas, dar efeito suspensivo aos recursos para evitar dano irreparável à parte (art. 14). Permite também a concessão de medida cautelar não apenas de caráter preventivo (como é da nossa tradição jurídica) mas também dotada de conteúdo executório, ou seja, a cautelar pode antecipar uma obrigação de fazer ou não fazer (coisa que, tradicionalmente, só é determinada com a sentença final), a fim de afastar 0 risco de grave lesão a tais direitos (art. 4). 0 alto grau de discricionaridade conferido ao juiz pela Lei $\mathrm{n}^{0} 7347 /$ 85 pode ser medido, ainda, pela possibilidade que ele tem de ampliar os limites do pedido da obrigação de fazer ou não fazer, se entender que a tutela do interesse ameaçado ou violado assim o requer, como também pela sua ampla margem de definição das medidas cominatórias (que visam obrigar o réu 
ao cumprimento da sentença), como o valor de multa diária a partir da decisão judicial até 0 seu efetivo cumprimento (Mancuso, 1994, pp. 7-10).

Entre 1985 e 1988, a ação civil pública teve aplicação restrita às questões de meio ambiente, consumidor e patrimônio histórico e cultural. ${ }^{10}$

A Constituição de 1988 consolidou as inovações processuais e de direitos substantivos introduzidas pela Lei da Ação Civil Pública, e foi além dela ao ampliar a lista de direitos que podem receber proteção via ACP e ao deixar uma porta aberta para outros que viessem a surgir no futuro, nos termos do art. 129: "São funções institucionais do Ministério Público: [...] III - promover 0 inquérito civil e a ação civil pública, para a proteção do patrimônio público e social, do meio ambiente e de outros interesses difusos e cletivos." Assim, a Constituição significou um duplo avanço: na medida em que ampliou os direitos coletivos e sociais (mesmo que de modo genérico), aumentou, automaticamente, o leque de interesses que podem ser protegidos pelo Ministério Público através da ação civil pública.

A consolidação constitucional de novos direitos substantivos e de instrumentos processuais antes dispersos em textos específicos foi decisiva também para o processo de legitimação do MP na sua pretensão de tornar-se agente defensor da cidadania. A partir de 1988, o MP passou a invocar a Constituição como uma espécie de certidão de (re)nascimento institucional, suficiente para habilitá-lo a ultrapassar suas funções tradicionais e reforçar sua responsabilidade pela defesa dos direitos coletivos e sociais. Não se pode dizer que o texto constitucional tenha definido perfeitamente 0 conteúdo desses direitos e os mecanismos judiciais para sua proteção. Ao contrário, ele apenas fornece as bases de uma nova arena de solução de conflitos coletivos, cuja construção depende em grande parte do processo subseqüente de afirmação institucional do MP e de avanços na regulamentação legislativa dos novos interesses e direitos.

Dentre os vários textos legais que regulamentaram essa nova arena de solução de conflitos coletivos, uma última referência torna-se obrigatória: 0 Código de defesa do onsumidor (CDC), instituído pela Lei $\mathrm{n}^{0}$ 8078, de 11 de setembro de 1990.
Enquanto o texto de 1988 deu status constitucional à ação civil pública, o CDC tratou de pormenorizar alguns aspectos até então não explicitados pelas leis anteriores. Dentre eles, deve-se destacar a definição dos direitos difusos, coletivos e individuais homogêneos e os efeitos da coisa julgada. ${ }^{11}$ O Quadro 1, baseado nos artigos 81 e 103 do CDC, resume esses dois pontos.

A partir dessas definições, podemos indicar também limites e contradições nesse novo campo que se abre no direito brasileiro com as ações coletivas. Inicialmente, deve-se ressaltar que tais interesses se encontram numa zona intermediária, às vezes nebulosa, entre a esfera dos direitos privados e a esfera pública. São interesses privados de dimensão coletiva, nas palavras de Ada Grinover. $^{13}$ Essa condição, por si só, representa inovação excepcional no quadro do direito tradicional, de matriz liberal clássica. Isto porque o direito moderno nasce da separação entre Estado e sociedade, entre esfera pública e esfera privada. Em conseqüência, os conflitos na esfera privada foram pensados como conflitos entre indivíduos isolados, entre particulares, e todo o aparato judicial foi estruturado de forma a solucionar tais demandas somente no julgamento de casos concretos, interindividuais, e com sentenças restritas às partes no processo. ${ }^{14}$ Essa individualização impediria, ao menos no nível institucional, a generalização dos conflitos, em particular aqueles que tivessem origem comum. Ora, é mais do que sabida a transformação social operada pela economia moderna, que reestruturou a sociedade em grupos, categorias e classes. Nada mais natural, portanto, do que 0 surgimento de conflitos baseados em interesses que, se são individuais juridicamente, são comuns ou coletivos na realidade social. A pressão sobre 0 ordenamento jurídico e sobre o próprio aparato judicial tem sido crescente nas últimas décadas, justamente na tentativa de forçá-los ao reconhecimento da dimensão coletiva de certos conflitos até então tratados individualmente.

0 reconhecimento legal de certos direitos difusos e coletivos tem outra implicação: a possibilidade de judicialização de conflitos políticos. Como veremos adiante, alguns direitos difusos e coletivos estão relacionados a políticas públicas e, 
Quadro 1

Direitos coletivos e efeitos da coisa julgada, segundo o CDC

\begin{tabular}{|c|c|c|}
\hline Interesses ou direitos & Definição segundo o CDC & E feitos da coisa julgada \\
\hline \multirow[t]{2}{*}{ Difusos } & $\begin{array}{l}\text { São os transindividuais de natureza } \\
\text { indivisível de que sejam titulares } \\
\text { pessoas indeterminadas e ligadas } \\
\text { por circunstâncias de fato. }\end{array}$ & $\begin{array}{l}\text { E rga omnes (contra todos), exceto } \\
\text { se o pedido for julgado improce- } \\
\text { dente por insuficiência de provas. }\end{array}$ \\
\hline & \multicolumn{2}{|c|}{$\begin{array}{l}\text { E x emplo: }{ }^{2} \text { destinatários de propaganda enganosa, veiculada em painéis } \\
\text { publicitários, jomais, revistas ou televisão. Trata-se de relação de consumo, } \\
\text { mas sem vínculo jurídico ou fático muito preciso, tanto que é impossível } \\
\text { identificar os titulares dos interesses e direitos envolvidos. Quando conde- } \\
\text { natória, a sentença protege de modo indeterminado todos os indivíduos que } \\
\text { estão sendo atingidos pela propaganda enganosa. }\end{array}$} \\
\hline \multirow[t]{2}{*}{ Coletivos } & $\begin{array}{l}\text { São os transindividuais de natureza } \\
\text { indivisível de que seja titular grupo, } \\
\text { categoria ou classe de pessoas liga- } \\
\text { das entre si ou com a parte contrária } \\
\text { por uma relação jurídica base. }\end{array}$ & $\begin{array}{l}\text { Ultra partes (além das partes), mas } \\
\text { restrita ao grupo, categoria ou clas- } \\
\text { se, salvo improcedência por insufi- } \\
\text { ciência de provas. }\end{array}$ \\
\hline & \multicolumn{2}{|c|}{$\begin{array}{l}\text { Ex emplo: aumento indevido das prestações de um consórcio. Como há } \\
\text { relação jurídica formalmente fixada, a sentença beneficia todas as vítimas } \\
\text { lesadas pelo réu, em uma ação promovida em nome dessa determinada } \\
\text { coletividade por um seu representante extraordinário. }\end{array}$} \\
\hline \multirow[t]{2}{*}{$\begin{array}{l}\text { Individuais } \\
\text { H omogêneos }\end{array}$} & $\begin{array}{l}\text { São os decorrentes de origem co- } \\
\text { mum. }\end{array}$ & $\begin{array}{l}\text { E rga omnes (contra todos), apenas } \\
\text { no caso de procedência do pedido, } \\
\text { para beneficiar todas as vítimas e } \\
\text { seus sucessores. }\end{array}$ \\
\hline & \multicolumn{2}{|c|}{$\begin{array}{l}\text { E x emplo: um certo bem de consumo, produzido em série, apresenta um } \\
\text { mesmo defeito, lesando os usuários finais. Nesse caso, um fato comum liga } \\
\text { inúmeros consumidores, mas que, por não estarem envolvidos por uma } \\
\text { relação jurídica, não podem ser determinados formalmente. A sentença, que } \\
\text { suspende a produção e pode implicar a reparação de danos, atinge a todos } \\
\text { os consumidores indistintamente. }\end{array}$} \\
\hline
\end{tabular}

portanto, ficam na dependência da ação governamental para serem efetivados. 0 ordenamento jurídico liberal clássico não desconhecia tais interesses e os conflitos em torno da sua aplicação prática. Ele apenas os reservava à esfera políticorepresentativa. Constitucionalizá-los também não significa necessariamente garantir sua efetividade. Constituições podem pairar solenes sobre a realida- 
de sem que o processo político seja capaz de trazêlas à terra. Novidade no caso brasileiro recente é a possibilidade de tais conflitos, antes restritos à esfera política, ganharem foro judicial e receberem solução mediante a aplicação técnica do direito. A este novo (des)encaminhamento de conflitos de interesse, da política para a Justiça, é que podemos denominar de judicialização da política. ${ }^{15}$

As ações coletivas também enfrentam dilemas decorrentes de sua definição legal. Como se trata de interesses difusos, o autor da ação civil pública não é 0 titular do interesse a ser tutelado, mas simplesmente 0 "representante" da coletividade em juízo. Tanto que as sentenças, quando estipulam indenização, revertem os recursos advindos da condenação a um fundo público encarregado de aplicá-los na reparação dos danos causados. Entretanto, com a legitimação concorrente instituída pela Lei $\mathrm{n}^{0}$ 7347/ 85, era de se esperar um vigoroso crescimento do número de associações civis de defesa dos interesses difusos e coletivos, promovendo ações judiciais nas mais diversas direções; afinal, a lei só exige um ano de existência e objetivos estatutários condizentes com a defesa desses interesses. Ao contrário, não ocorreu nenhum crescimento significativo nesse sentido e hoje o MP é o responsável pela maior parte das ações civis públicas em tramitação na Justiça. Mais do que isso, o Judiciário tem oposto resistência à construção dessa legitimidade ex traordinária ${ }^{16}$ até mesmo quando o autor é o Ministério Público. Argumentam os juízes que, em muitos casos, os próprios titulares de direitos lesados é que deveriam ingressar em juízo, e, sendo esses direitos disponíveis, não cabe ao MP ou qualquer outro agente avocar para si a tarefa de defendê-los. Várias ações coletivas são hoje indeferidas preliminarmente por ilegitimidade dos autores. Segundo os promotores entrevistados, este problema se explica principalmente pelo fato de estarmos lidando com uma ação de tipo coletivo sob um ordenamento jurídico de princípios essencialmente individualistas. ${ }^{17}$

O efeito erga omnes da coisa julgada para os casos difusos e individuais homogêneos e 0 efeito ultra partes para 0 caso coletivo amplificam 0 resultado de uma decisão judicial para toda a coletividade. Se for julgada procedente, uma única ação coletiva pode beneficiar todos os que se encontram ligados por circunstâncias de fato ou por uma relação jurídica com a parte contrária. Segundo Mancuso, as ações coletivas confrontam um dos princípios clássicos do processo judicial: o de que a sentença faz coisa julgada às partes entre as quais é dada, não afetando positiva ou negativamente a vida de terceiros (Mancuso, 1994, p. 167). No Brasil, a amplitude dos efeitos da coisa julgada em ações coletivas é um dos pontos mais polêmicos e ainda não sedimentados na área processual. Tal indefinição foi em parte superada recentemente pela Medida Provisória $\mathrm{n}^{0}$ 1570-5, convertida na Lei $\mathrm{n}^{0}$ 9494, de 10 de setembro de 1997, que fixou no seu artigo 16 que "a sentença civil fará coisa julgada erga omnes, nos limites da competência territorial do órgão prolator, exceto se o pedido for julgado improcedente por insuficiência de provas, hipótese em que qualquer legitimado poderá intentar outra ação com idêntico fundamento, valendo-se de nova prova" (grifo meu). Ou seja, antes dessa definição, uma sentença judicial de primeira instância em qualquer comarca do país teria, em tese, efeito sobre todo o território nacional. Agora, com a nova lei, o efeito atinge a todos, mas apenas dentro da área territorial sob a jurisdição do órgão que tomou a decisão. Em termos jurídicos, entretanto, tal restrição pode ser tão inócua quanto 0 princípio anterior (efeito erga omens sobre todo 0 territónio nacional), uma vez que a própria definição de direitos difusos e individuais homogêneos não comporta limitação jurisdicional de tipo territorial. Os limites da coisa julgada, nesses casos, tendem a permanecer incertos até que 0 Judiciário forme juízo definitivo sobre a questão.

Por último, e talvez seja o ponto mais importante desta discussão, deve-se registrar a profunda alteração produzida por esses textos legais no papel institucional do Ministério Público. Sabe-se que a Constituição de 1988 definiu de forma bastante ampla e às vezes genérica os direitos individuais, coletivos e sociais. Um exemplo importante é o seu art. 6: "São direitos sociais a educação, a saúde, o trabalho, o lazer, a segurança, a previdência social, a proteção à maternidade e à infância, a assistência aos desamparados, na forma dessa Constituição". Obviamente, tal determinação constitucional não representa nenhuma novidade, nem 
aqui nem no direito comparado. Normas como essa são chamadas normas programáticas, inseridas nos textos constitucionais como uma espécie de "conselho" aos governantes, que devem perseguir esses objetivos como forma de promover o bem comum. Novidade no nosso caso é que a defesa de tais interesses foi colocada como função institucional de um órgão do próprio Estado, o Ministério Público. Diz 0 art. 127 da Constituição: "O Ministério Público é instituição permanente, essencial à função jurisdicional do Estado, incumbindo-lhe a defesa da ordem jurídica, do regime democrático e dos interesses sociais e individuais indisponíveis." Se antes, na esteira da tradição liberal-democrática, normas programáticas tinham de ser invocadas pela sociedade no terreno da luta política, hoje, de acordo com a Constituição, elas podem e têm sido levadas aos tribunais por obra principalmente do Ministério Público. Enquanto a sua execução dependia em geral da vontade do governante, mediante os incentivos e constrangimentos próprios do processo político, agora essa execução pode ser cobrada do poder público por um órgão do próprio Estado numa instância não política de resolução de conflitos: a instância judicial.

A outra face da judicialização dos conflitos políticos é a politização dos órgãos da Justiça, especialmente o Ministério Público. A Constituição e as leis vistas acima politizaram as atribuições do MP, lançando-0 no turbilhão dos conflitos coletivos, sociais e políticos. O adensamento dessas novas atribuições só foi possível, entretanto, porque ao seu lado a Constituição instituiu prerrogativas e garantias funcionais para promotores e procuradores tão abrangentes quanto aquelas encontradas no Judiciário. Refiro-me a independência funcional, vitaliciedade, inamovibilidade e irredutibilidade de vencimentos. A garantia de independência no exercício de suas funções permite aos integrantes do MP atuarem com desenvoltura e autonomia - particularmente nos conflitos de dimensão social e política - , contra as pressões externas e até mesmo internas advindas dos estratos superiores da instituição. $\mathrm{Na}$ verdade, mal se pode falar em hierarquia quando descrevemos a organização interna do MP. Ela ocorre apenas no sentido administrativo e não é capaz de atingir a esfera funcional de seus integran- tes (Mazzilli, 1993, pp. 66 e 72). As demais garantias impedem que um membro do MP seja demitido, a não ser por sentença judicial (vitaliciedade), que seja removido compulsoriamente de um lugar para outro (inamovibilidade) ou que seu salário seja reduzido (irredutibilidade de vencimentos). Resultante de uma longa batalha pela equiparação com a magistratura, a extensão dessas garantias ao MP não pode ser vista como conquista corporativa em sentido fraco (quando garantias não passam de privilégios), mas como complemento importante do processo de politização de suas atribuições. Em outras palavras, tais garantias não são suficientes para o bom desempenho da instituição como um todo, mas são necessárias para aqueles integrantes do MP que assumiram seu papel político excepcional e procuram levar às últimas conseqüências suas novas tarefas constitucionais.

\section{A judicialização da política e a politização da Justiça na visão dos integrantes do Ministério Público}

Após a promulgação da Constituição de 1988, o sentido geral dessas mudanças legais ganhou expressão no debate público mediante a seguinte formulação: 0 Ministério Públion deix ou de ser defensor do Estado para ser defensor da sociedade. A função principal seria ainda a de fiscal da lei, mas com uma clara inversão de sentido: finalmente independente do Poder Executivo, colocado criativamente pelo constituinte em um capítulo à parte dos três poderes (intitulado "Das funções essenciais à Justiça"), com a prerrogativa de propor seu próprio orçamento, e com autonomia funcional e administrativa, o MP passaria a fiscal da aplicação da lei em benefício da sociedade e não mais do Estado. ${ }^{18}$ Além de fiscal da lei, já vimos como a Constituição consagrou a idéia de um ministério público também legitimado a agir, não mais como mero assistente, mas como autor, ele mesmo, de ações em defesa dos interesses difusos e coletivos. Muito provavelmente, a conjunção dessas duas mudanças fundamentais é a origem de outra idéia também amplamente veiculada nesse período: a de que a Constituição de 1988 havia criado um quarto poder. ${ }^{19}$ 
Todas as mudanças legais e constitucionais já seriam suficientes para uma análise da novidade que representa o MP brasileiro hoje. Entretanto, tão ou mais importante que os aspectos formais dessa mudança é a dimensão da ação concreta, orientada por uma visão doutrinária bastante peculiar, dos integrantes dessa instituição. Do ponto de vista da atuação de promotores e procuradores de justiça, julgo que temos assistido nos últimos anos a um processo de reconstrução institucional talvez sem paralelo na história do país. Os primeiros resultados da pesquisa empírica demonstram que esse processo tem fortes traços endógenos: os próprios integrantes do MP, imbuídos da convicção de colocar a instituição a serviço da construção da cidadania, têm desenvolvido ações dentro e fora de seu círculo normal de atribuições visando a mudanças legais e constitucionais capazes de alterar profundamente seu papel institucional, e isso pelo menos desde 0 início dos anos 80. E mais: é preciso lembrar que estamos falando de um processo de reconstrução institucional sem qualquer mecanismo externo de impulsão (algo como o sistema partidário e 0 momento eleitoral para os poderes Legislativo e Executivo), mas decorrente essencialmente da vontade política dos próprios integrantes da instituição. ${ }^{20}$

\section{A crítica aos poderes polítios}

Como os membros do MP avaliam as mudanças recentes na instituição? Quais as principais dificuldades que têm enfrentado na reconstrução de seu papel institucional? Consideram esse processo algo linear ou são capazes de reconhecer os limites e contradições dessas novas tarefas? Estas foram algumas das questões que nortearam nossas entrevistas com promotores e procuradores de justiça no survey "O Ministério Público e a Justiça no Brasil". ${ }^{21}$

Dentre as várias questões abordadas no survey, selecionei para este texto aquelas que me permitissem tratar do seguinte problema: como os integrantes do Ministério Público comparam sua responsabilidade pela crise da Justiça com a de outras instituições direta e indiretamente ligadas à prestação jurisdicional? Nessa mesma direção, co- mo comparam sua contribuição para 0 alargamento e consolidação de novos direitos com a de outros agentes públicos e da sociedade civil? A comparação de responsabilidades pela crise e de contribuições à promoção de direitos entre as instituições foi complementada com o uso de questões que permitissem verificar os valores que têm orientado a atuação de promotores e procuradores. Ao final, 0 que procuro demonstrar é que os integrantes do MP têm uma avaliação bastante crítica da sociedade civil (tanto de suas carências quanto de sua incapacidade de mobilização e luta) e também dos poderes de Estado (que são vistos como os grandes culpados pela ineficiência da Justiça e pelo desrespeito constante dos direitos constitucionais do cidadão), o que nos permite aventar a hipótese de que os valores subjacentes a essa avaliação crítica remontam a uma corrente ideológica importante e tradicional na vida política brasileira que, diante da fragilidade da sociedade civil e da situação deteriorada dos poderes políticos, busca de modo voluntarista soluções alternativas antipolíticas.

\section{A responsabilidade pela crise da Justiça}

Como mostra o Gráfico 1, promotores e procuradores responsabilizam os agentes políticos, externos ao sistema de justiça, mais do que a si próprios, advogados e Poder Judiciário, pela crise na Justiça. Entre os agentes políticos, os de nível federal são mais responsabilizados pela crise do que os de nível estadual.

A tendência de atribuir maior responsabilidade pela crise a agentes extemos ao sistema judicial é dominante entre membros do MP, da mesma forma que entre seus colegas magistrados, como demonstrou pesquisa realizada pelo Instituto de Estudos Econômicos, Sociais e Políticos de São Paulo (Idesp) em 1993. ${ }^{22}$ Judiciário e Ministério Público, no quadro mais amplo das instituições, são considerados, por seus respectivos integrantes, eternos reféns dos poderes políticos. Magistrados afirmam freqüentemente que, dentre os poderes da República, o Judiciário é o que menos tem poder. Não tem controle sobre a força nem o dinheiro; não pode tomar resolução ativa pois é inerte. ${ }^{23}$ Sua tarefa é apenas aplicar a lei, e de preferência sem muita interpretação subjetiva. Promotores e procu- 
Gráfico 1

Grau de responsabilidade pelo mau funcionamento da Justiça no Brasil

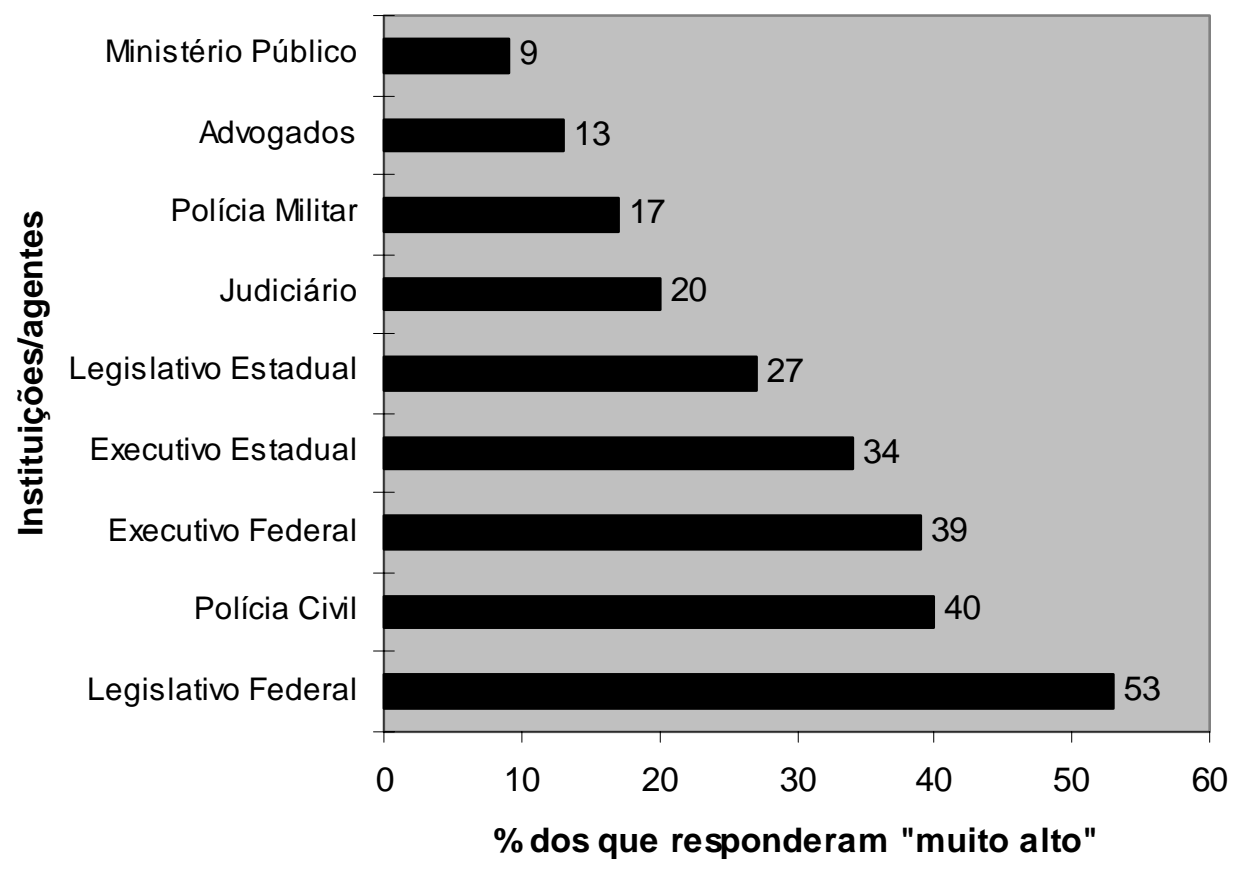

radores também se queixam corporativamente do mau tratamento que o Legislativo e o Executivo dispensam às instituições judiciais. Mais do que isso, na fase atual, integrantes do Ministério Público têm apontado 0 próprio Estado, em especial os poderes políticos, como o principal responsável pelas mazelas da sociedade. Se cabe ao MP defendê-la, muitos consideram que sua luta principal será contra o próprio Estado.

De fato, como mostra a Tabela 1, os integrantes do Ministério Público explicitam o conflito entre os poderes a ponto mesmo de indicar a existência de interferência indevida do Poder Executivo, federal e estadual, nos órgãos judiciais.

O Gráfico 2 mostra como integrantes do MP avaliam as principais instituições do sistema de Justiça e do sistema político. Coincidindo com sua percepção sobre a responsabilidade pela crise da Justiça, avaliam positivamente 0 seu próprio desempenho e de seus colegas do meio forense, e avaliam negativamente 0 desempenho dos pode- res políticos executivos e legislativos, nos níveis estadual e federal.

Tabela 1

Interferência indevida do Poder Executivo (estadual e federal, conforme o caso) no Poder Judiciário e no Ministério Público (em \%)

\section{Interferência indevida do} Poder Executivo

Instituições Muita Alguma Nenhuma Sem opinião

$\begin{array}{lllll}\text { Poder Judiciário } & 21 & 56 & 10 & 13\end{array}$

Federal

$\begin{array}{lllll}\text { Poder Judiciário } & 25 & 57 & 13 & 5\end{array}$

Estadual

Ministério Público $18 \quad 54 \quad 12 \quad 16$

Federal

Ministério Público $16 \quad 59 \quad 20 \quad 5$

Estadual 
A mpliação e consolidação de novos direitos

Como vimos, a atribuição do MP de defender os interesses e direitos transindividuais é relativamente recente. Na verdade, é algo mais amplo do que uma renovação de atribuições que está em jogo nesse caso. Refiro-me ao fato de que o próprio ordenamento jurídico brasileiro, de matriz liberalindividualista, vem passando por profundas alterações à medida que direitos de dimensão coletiva têm sido instituídos e que novos procedimentos judiciais têm possibilitado a busca de sua efetividade. 0 impacto dessas mudanças jurídicas já se faz sentir em áreas como defesa do consumidor, meio ambiente, controle da administração pública e até serviços de relevância pública envolvendo direitos sociais básicos. Hoje, crianças de rua, usuários de transportes públicos, consumidores, contribuintes, usuários de serviços públicos de saúde e educação, para citar alguns exemplos, têm sido amparados por ações coletivas promovidas pelo Ministério Público. 0 meio ambiente e o patrimônio histórico e cultural também ganharam um forte aliado nos últimos anos, ao passo que os administradores públicos talvez nunca tenham tido um fiscal tão atento, atuante e com razoável poder de fogo como o Ministério Público.

A possibilidade de preservar direitos fundamentais de tipo coletivo ou social mediante mecanismos judiciais pressupõe que tais direitos tenham sido previamente "positivados". Em outras palavras, pressupõe um processo pelo qual a sociedade logra inscrever nos diplomas legais direitos almejados. No

Gráfico 2

Avaliação do desempenho de órgãos e poderes nos últimos 12 meses

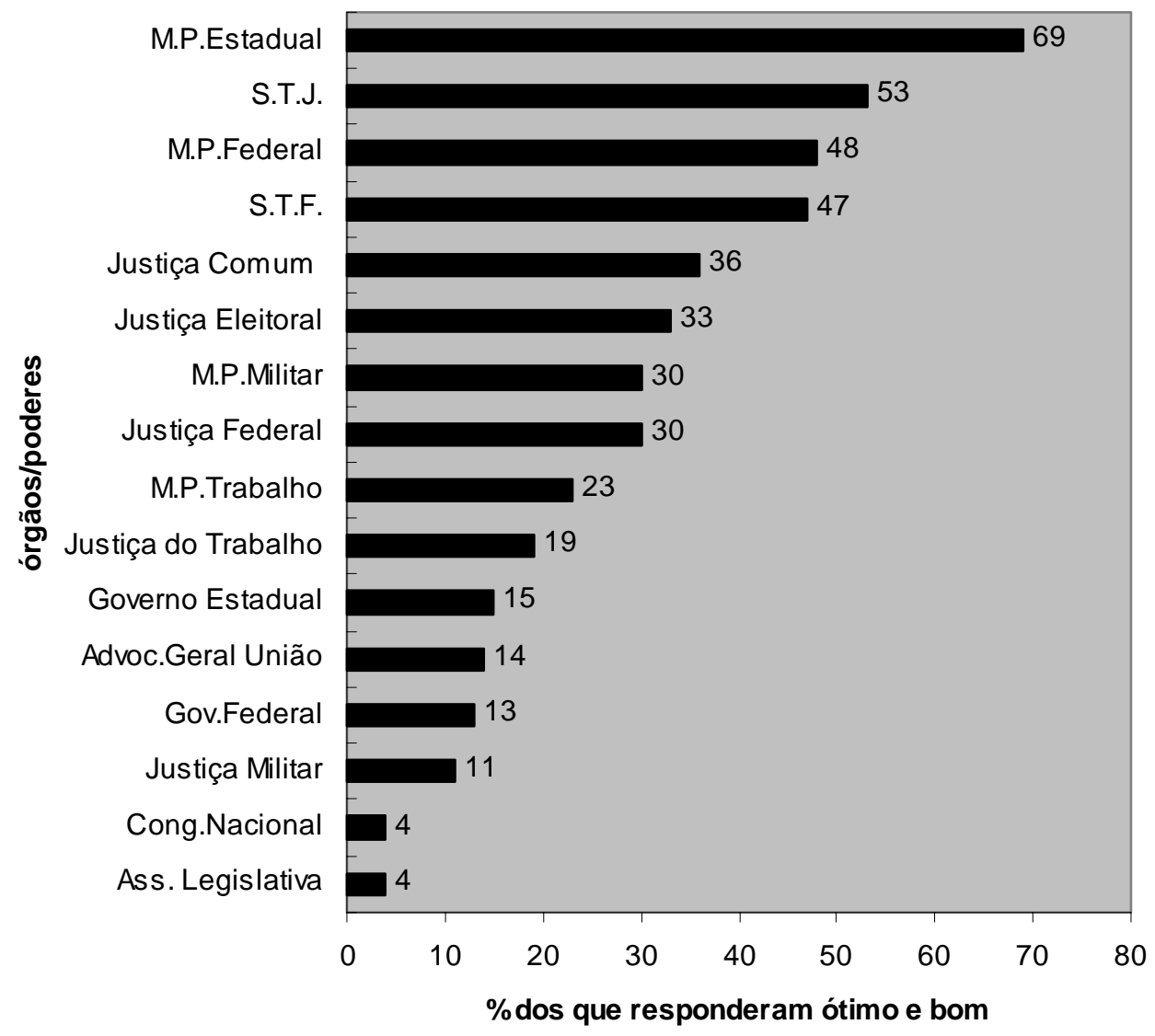


modelo liberal-democrático, tal processo é considerado essencialmente político: depende das forças em jogo e, se minimamente institucionalizado, terá lugar em instituições representativas a partir da sociedade civil (sindicatos, associações, movimentos etc.), passando pelos partidos políticos até aquelas propriamente estatais, como os poderes Executivo e Legislativo, estaduais e federais. 0 sistema de justiça, embora possa excepcionalmente ensejar mudança social, foi pensado e estruturado para ratificar direitos previamente forjados pela sociedade e positivados pelo direito estatal.

O Gráfico 3 mostra, de forma paradoxal, que integrantes do MP consideram que 0 processo de alargamento e consolidação de novos direitos no Brasil não tem seguido a seqüência apontada acima.

Promotores e procuradores vêem a si próprios como os que mais têm contribuído para o alargamento e consolidação de direitos difusos e coletivos. Mais significativo do que isso, entretanto, é o lugar que ocupam os partidos políticos e os poderes Legislativo e Executivo: paradoxalmente, os agentes tradicionais da política estão em último lugar na produção e preservação de direitos, segundo os entrevistados. Acima de 50\% aparecem apenas a sociedade civil organizada, órgãos públicos como os Procon's e delegacias especializadas, e imprensa.

\section{A "hipossuficiência" da sociedade brasileira e o papel das instituições de Justiça}

A observação da atuação de integrantes do MP tem possibilitado verificar que o processo de reconstrução institucional a que nos referimos acima baseia-se na atuação estratégica, se não de todos, pelo menos de grupos destacados de promotores e procuradores. Essa atuação se dá em diversas frentes: no cotidiano de juízos e tribunais do país, assistimos promotores e procuradores buscando romper bases tradicionais do ordenamento jurídico por meio de ações de conteúdo inovador, muitas vezes sem o amparo de legislação infraconstitucional e invocando diretamente a Constituição.

Gráfico 3

Grau de contribuição de diversos agentes

ao alargamento e consolidação dos direitos difusos, coletivos $\mathrm{e}$ individuais homogêneos

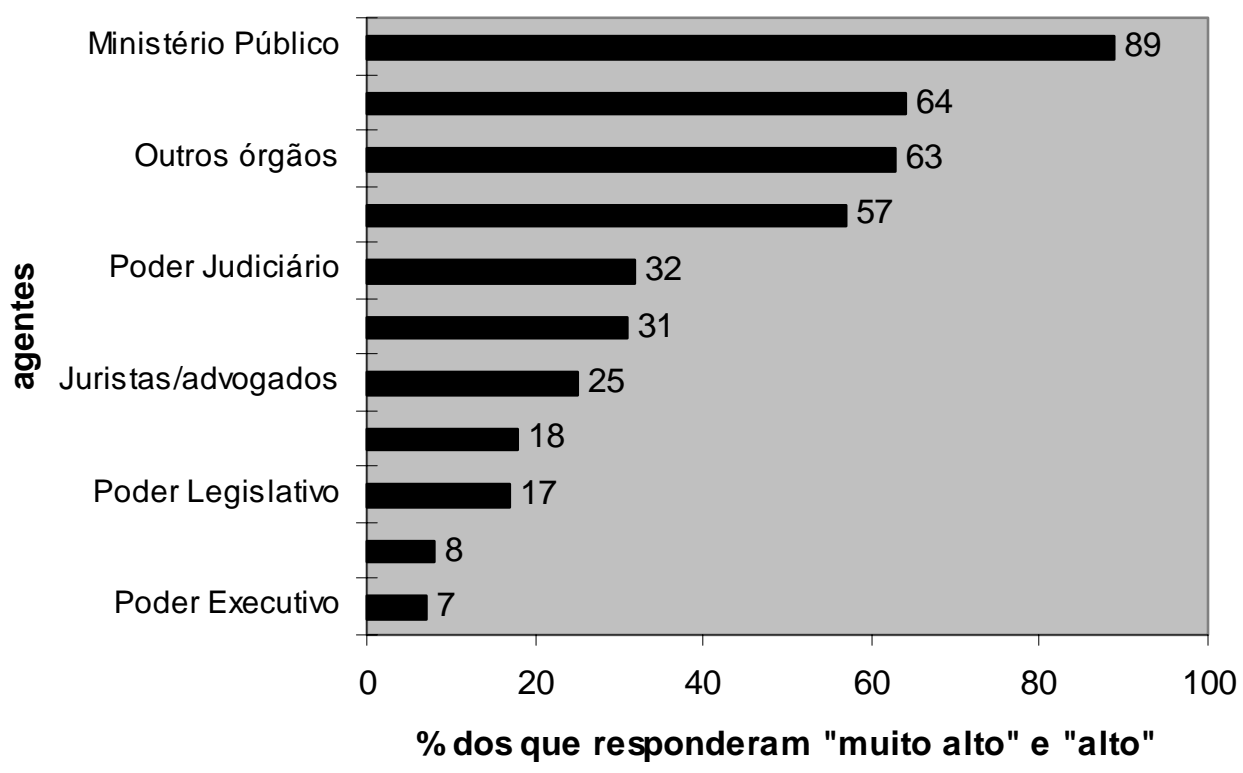


Em geral, essas ações buscam alargar o acesso de demandas coletivas à Justiça, cujo sucesso depende da eficácia das mesmas em derrubar dogmas do direito liberal-individualista. Além da atuação propriamente judicial, as associações de classe do MP, estaduais e federais, têm acompanhado e procurado influenciar a produção legislativa parlamentar, não só de seu interesse corporativo, mas também de normas gerais relativas a direitos de cidadania em diversas áreas (consumidor, meio ambiente, sistema tributário, previdência social).
Essa atuação engajada, como parte importante da reconstrução institucional do MP, parece estar sendo guiada por uma interpretação bastante peculiar do processo político e da promoção da justiça no Brasil.

Conforme mostra a Tabela 2, 84\% dos entrevistados concordam total ou parcialmente com a afirmação de que "A sociedade brasileira é hipossuficiente, isto é, incapaz de defender autonomamente os seus interesses e direitos, e que, por isso, as instituições da justiça devem atuar afirmativamente

Tabela 2

Questões sobre o papel da Justiça na sociedade brasileira

\begin{tabular}{|c|c|c|c|}
\hline & $\begin{array}{l}\text { Concorda } \\
\text { totalmente ou } \\
\text { em termos }\end{array}$ & $\begin{array}{l}\text { D iscorda } \\
\text { totalmente ou } \\
\text { em termos }\end{array}$ & $\begin{array}{c}\text { Sem } \\
\text { opinião }\end{array}$ \\
\hline $\begin{array}{l}\text { "A sociedade brasileira é hipossuficiente, isto é, incapaz de } \\
\text { defender autonomamente os seus interesses e direitos, e [...], } \\
\text { por isso, as instituições da Justiça devem atuar afirmativa- } \\
\text { mente para protegê-la." }\end{array}$ & 84 & 12 & 4 \\
\hline “O direito positivo não permite o espírito crítico.” & 34 & 63 & 3 \\
\hline "O saber jurídico está dissociado da realidade brasileira." & 51 & 46 & 3 \\
\hline $\begin{array}{l}\text { "O juiz não pode ser um mero aplicador das leis, tem de ser } \\
\text { sensível aos problemas sociais." }\end{array}$ & 93 & 5 & 2 \\
\hline $\begin{array}{l}\text { "O compromisso com a justiça social deve preponderar } \\
\text { sobre a estrita aplicação da lei." }\end{array}$ & 72 & 26 & 2 \\
\hline "A aplicação da lei sempre beneficia os privilegiados." & 44 & 54 & 2 \\
\hline "A maior parte da população não tem acesso à Justiça." & 78 & 20 & 2 \\
\hline $\begin{array}{l}\text { "O Ministério Público deve ser canal de demandas sociais } \\
\text { com vistas ao alargamento do acesso à Justiça, transforman- } \\
\text { do o Judiciário em um lugar privilegiado para a solução de } \\
\text { conflitos coletivos." }\end{array}$ & 86 & 11 & 3 \\
\hline $\begin{array}{l}\text { "Cabe obrigatoriamente ao Ministério Público exigir da } \\
\text { administração pública que assegure os direitos previstos na } \\
\text { Constituição Federal, nas leis e nas promessas de campanha } \\
\text { eleitoral. Quando houver lei garantindo os direitos, não há } \\
\text { discricionaridade administrativa." }\end{array}$ & 87 & 11 & 2 \\
\hline $\begin{array}{l}\text { "O Ministério Público deve desempenhar o papel de promo- } \\
\text { ção da conscientização e da responsabilidade da sociedade } \\
\text { brasileira." }\end{array}$ & 85 & 14 & 1 \\
\hline
\end{tabular}


para protegê-la". Esse tipo de diagnóstico da sociedade brasileira, embora não seja novidade na história política do país nem obra exclusiva dos integrantes do Ministério Público, parece estar orientando a ação de setores importantes da instituição.

Dentre várias opiniões exemplares nesse sentido, cabe registrar aqui a de Ana Lúcia Amaral, procuradora da República em São Paulo:

Ao estabelecer o constituinte, como função institucional do Ministério Público, a promoção da ação civil pública para a defesa coletiva dos direitos, quer individuais quer coletivos, demonstrou sensibilidade, e estar atento à situação de marginalidade em que vive parte expressiva da população, flagrantemente hipossuficiente face os chamados Poderes públicos. Por não se encontrar, ainda, a sociedade civil devidamente organizada, de sorte a defender, através de associagões e outros entes, os seus interesses, no atendimento de suas necessidades, incumbe no momento ao Ministério Públion, precipuamente por força de sua função institucional, trazer ao Poder Judiciário as grandes questões, já que os outros Poderes do Estado, por sua própria natureza, não poderiam dirimilas, além do que, em muitas oportunidades, atuam contra os direitos fundamentais dos cidadãos. (Amaral, 1992; grifos meus)

0 argumento é que temos uma sociedade civil fraca, desorganizada e incapaz de defender seus direitos fundamentais. Uma sociedade "hipossuficiente" no jargão jurídico. Além disso, freqüentemente é 0 próprio poder público quem mais desrespeita esses direitos fundamentais. ${ }^{24}$ Dessa equação resulta a proposta, de natureza instrumental, de que "alguém" deve interferir na relação Estado/ sociedade em defesa dessa última. Instrumental no sentido de que não é para sempre: pelo menos no plano imediato, no momento, "alguém" tem de tutelar os direitos fundamentais do cidadão até que ele mesmo, conscientizado pelo exemplo da ação de seu protetor, desenvolva autonomamente a defesa de seus interesses. Essa visão do papel do MP e da Justiça é confirmada pela maioria dos integrantes da instituição, conforme mostra a Tabela 2: 85\% concordam que o Ministério Público deve promover a conscientização da sociedade brasileira.

A referida fragilidade da sociedade brasileira e sua incapacidade crônica de manter sob controle - Estado é um desses lugares-comuns da nossa história política. Dessa chave teórica é comum emergir denúncias sobre 0 artificialismo de nossas instituições políticas, especialmente as representativas, e a crítica da nossa tradição constitucional desprovida de mecanismos de enforcement, daí resultando a necessidade também crônica que temos de um poder externo, independente de controles, muitas vezes irresponsável perante a sociedade, mas que justamente por isso - segue 0 argumento - goza de autonomia suficiente para tutelá-la e conduzi-la com desenvoltura. Como sabemos, 0 abismo entre 0 mundo das instituições políticas e o mundo real constitui-se em uma das idéias mais invocadas no debate público brasileiro, tem sido partilhada por um amplo espectro ideológico e já serviu de justificativa para ações políticas de grande impacto. A oposição entre instituições político-representativas degeneradas e sociedade civil fraca está entre as idéias principais que têm norteado a ação de setores do MP e seu processo de reconstrução institucional tem sido marcado pela presença de valores remanescentes dessa poderosa tradição de pensamento político. Obviamente, 0 novo ambiente institucional torna necessária uma atualização desses valores, como, por exemplo, 0 fato distintivo de que as pretensões políticas do MP (que nos permitem associá-lo àquela tradição de pensamento crítico) não são resultado de mera arvoragem, mas estão inscritas de forma inequívoca na própria Constituição. ${ }^{25}$

Outra inovação em relação a essa tradição reside no fato de que a solução proposta para os conflitos coletivos, em particular aqueles em que 0 Estado figura como réu, é uma solução não só judicial como antipolítica. Como mostra a Tabela 2, 86\% dos integrantes do Ministério Público concordam que ele "deve ser canal de demandas sociais com vistas ao alargamento do acesso à Justiça, transformando o Judiciário em um lugar privilegiado para a solução de conflitos coletivos". $\mathrm{Ou}$ seja, é preciso que o MP traga as grandes questões ao Judiciário, e que este funcione como 
instância de substituição ${ }^{26}$ dos poderes políticos, incapazes que estão de atender aos apelos da sociedade, por omissão ou mesmo por má-fé. Como muitas vezes o agente agressor dos direitos coletivos é o próprio Estado, não há entre promotores e procuradores esperança de que as instituições políticas sejam capazes de deslanchar qualquer processo consistente de efetivação de direitos constitucionais. Há quem afirme que, por essas e outras razões, o Ministério Público transitou da sociedade política para o âmbito da sociedade civil. É o que dizem Machado e Goulart (1992, p. 33), depois de citarem a distinção entre sociedade política e sociedade civil elaborada por Gramsci: "A evolução histórica do Ministério Público revela essa gradativa mudança de função como o sinal inequívoco do seu deslocamento institucional na superestrutura do Estado. Passando de procuradoria do rei à defensoria do povo, o Ministério Público brasileiro, com estruturação jurídico-formal das mais modernas, hoje é um organismo que integra e representa a sociedade civil."

Se estivéssemos falando da discussão tradicional sobre a defesa das liberdades e direitos individuais pelo Judiciário, diante das ações lesivas do poder público, certamente não estaríamos acrescentando nada de novo. 0 debate é clássico e insolúvel: até que ponto o Judiciário pode interferir nas ações de governo em defesa do indivíduo? Até que ponto 0 poder público pode subjugar os direitos individuais em nome das razões de Estado? A não ser do ponto de vista normativo, estas questões fundamentais não foram resolvidas pela teoria política e talvez nunca o sejam. Mas o fato é que estamos falando de direitos novos, de direitos difusos, coletivos e sociais consagrados pela Constituição. E o que é mais significativo: de uma Constituição que outorgou a um órgão do próprio Estado, o Ministério Público, a função de defender em juízo direitos como "a educação, a saúde, o trabalho, o lazer, a segurança, a previdência social, a proteção à matemidade e à infância, a assistência aos desamparados" (artigos 6 e 127), e ainda o patrimônio público e social, o meio ambiente e toda sorte de interesses difusos e coletivos (art. 129). Tudo isso mediante um instrumento sem similar no direito comparado: a ação civil pública. ${ }^{27}$
A atuação do MP na área dos serviços de relevância pública ainda é incipiente. $\mathrm{Na}$ falta de uma regulamentação legislativa adequada, promotores de justiça formulam suas ações coletivas em defesa de direitos sociais - como saúde, educação e outros - invocando diretamente a Constituição, exigindo um esforço especial de interpretação por parte dos magistrados que podem decidir preliminarmente sobre a aceitação dessas ações. Apesar de incipientes, as demandas relativas a direitos sociais tendem a ser as mais problemáticas do ponto de vista institucional. Como vimos, fala-se no binômio Ministério Público-Judiciário como instância de substituição dos poderes Legislativo e Executivo. Se juntarmos a isso a abrangência dos direitos constitucionais do cidadão, a obrigatoriedade da prestação dos serviços de relevância pública pelo Estado, sob pena de incorrer em inconstitucionalidade por omissão, e a função precípua do MP de zelar pelo seu efetivo cumprimento, teremos todos os elementos suficientes para compreender a novidade e os limites desse sistema institucional.

Como novidade, este quadro institucional representa a possibilidade de uma ampla judicialização de conflitos políticos em nome da busca da efetividade dos direitos constitucionais do cidadão. Dentre os limites, podemos relacionar os seguintes: como combinar a legitimação extraordinária conferida ao MP para representar toda a coletividade em juízo e a ausência de controle social sobre a instituição? Como garantir sua independência diante da crescente politização de suas funções? Como órgão estatal, sem legitimidade eleitoral, pode o MP atuar de forma eficaz quando o agente agressor é 0 próprio Estado? Os critérios jurídicos de decisão forjados na instância MP-Judiciário, em particular nos casos de prestação de serviços públicos, são compatíveis com os critérios políticos e de administração da coisa pública forjados na instância Legislativo-Executivo ${ }^{28}$

Os integrantes do Ministério Público muitas vezes subestimam essas questões. $\mathrm{Na}$ verdade, buscam reduzir sua complexidade por meio da argumentação de que não se pode ter dúvidas sobre o papel desempenhado pelo MP porque, para além das injunções políticas, sua tarefa constitucional é simplesmente cuidar da aplicação da 
lei, com toda força que esta expressão possa conter. Se a lei existe, ela precisa ser cumprida. 0 argumento chega a valer para as normas constitucionais programáticas:

A atuação nossa nessa área é muito difícil. A Constituição garante uma série de direitos e a Constituição não é letra morta. Embora alguns autores [...], muita gente entenda que determinadas normas contidas na Constituição sejam normas programáticas, ou seja, que no futuro próximo ou remoto se busque alcançar a finalidade prevista, eu já sou de opinião totalmente contrária, eu acho que a Constituição, principalmente uma Constituição rígida, escrita, como a nossa, não existe para aconselhar ninguém, ou pra pre ver um futuro melhor [...] Por exemplo, no caso da saúde, que é direito do povo e dever do Estado, embora essa norma chamada programática não te permita propor uma ação com objeto fixo (0 Executivo deve fazer "isso" para cumpri-la), por outro lado ele não pode descumprir esse princípio, que não deixa de ser um princípio constitucional. Então, ele não pode violar; sendo programática ou não essa norma, ele não pode violar [...] Se é dever dele, ele deve fazer tudo que ele pode, inclusive porque qualquer atuação contrária a esse princípio, programático ou não, é inconstitucional, por omissão. (Promotor 4, grifos meus)

Essa idéia é amplamente compartilhada pelos integrantes do MP, conforme mostra a Tabela 2: $87 \%$ dos entrevistados concordam que "cabe obrigatoriamente ao Ministério Público exigir da administração pública que assegure os direitos previstos na Constituição Federal, nas leis e nas promessas de campanha eleitoral. Quando houver lei garantindo os direitos, não há discricionaridade administrativa." Ou seja, a alegação de restrição orçamentária ou outros motivos normalmente invocados para sustentar decisões sobre políticas públicas em situação de escassez não afastam de apreciação judicial a conduta política do administrador público, segundo os entrevistados.

Se este novo quadro institucional, associado ao voluntarismo dos membros do MP, representa uma possibilidade de judicialização dos conflitos políticos, de outro lado isto tem significado também uma crescente politização da instituição, e em duplo sentido: do ponto de vista do arranjo institucional de poderes, o MP rompeu o isolamento do sistema judicial para se constituir em ator relevante no processo político, interferindo muitas vezes de modo decisivo na dinâmica entre os poderes; internamente, a politização também vem ocorrendo no sentido de um posicionamento ideológico de seus integrantes diante dos desafios de redução de desigualdades sociais e ampliação da cidadania.

Essa politização pode representar uma ameaça à independência institucional do Ministério Público, pelo menos nas condições em que ela se assenta hoje. Embora a forma de ingresso na carreira, através de concurso público, bem como outros aspectos corporativos contribuam para afastar da instituição as correntes político-partidárias, de outro lado a participação do Poder Executivo na escolha dos chefes dos MPs estaduais e do MP federal tem resultado em nomeações marcadas pelo critério de alinhamento com o governo, numa clara tentativa de controlar "por cima" essa poderosa organização.

Independente das indefinições restantes desse novo quadro institucional, o fato é que a politização de suas atribuições e o voluntarismo de seus integrantes transformaram o Ministério Público em um dos agentes principais do processo político no país. Seu combustível, embora reciclado, tem alto poder de explosão: a crença de que a sociedade civil é hipossuficiente, de que os poderes políticos estão degenerados, e alguém precisa fazer alguma coisa.

\section{NOTAS}

1 Analiso o sistema de controle constitucional brasileiro em Arantes (1997).

2 Para uma análise das funções tradicionais do Ministério Público brasileiro e suas novas atribuições, ver Macedo Jr (1995) e Mazzilli (1994).

3 Para uma discussão mais aprofundada nesse sentido, teórica e aplicada ao contexto brasileiro recente, ver Faria (1994).

4 Rodolfo Mancuso, cujo trabalho é a referência nesta parte, demonstra, através da análise da Exposição de 
Motivos do Projeto de Lei que deu origem à Lei $\mathrm{n}^{0} 7347 /$ 85, como aquelas leis ordinárias e complementares obrigaram o legislador a disciplinar, num texto à parte, a ação civil pública. Ver Mancuso (1994, p. 21).

5 No primeiro grau de jurisdição ou instância, o integrante do MP estadual é denominado promotor de justiça. No segundo grau ou instância ele é denominado procurador de justiça. No MP federal, o integrante que atua na primeira instância denomina-se procurador da República e 0 que atua na segunda instância denomina-se procurador regional da República.

6 Segundo Ada Pelegrini Grinover, "0 texto legal fala impropriamente em ação civil pública. Impropriamente, porque nem a titularidade da ação é deferida exclusivamente a órgãos públicos (MP, União, estados e municípios), nem é objeto do processo a tutela do interesse público." Cf. Ada Grinover, "Ações coletivas para a tutela do ambiente e dos consumidores", Selecóes Jurídicas, apud Mancuso (1994, p. 17). Ou seja, a própria denominação "civil pública" não representa de forma adequada 0 conteúdo expresso em termos de titularidade e objeto da ação prevista pela Lei $\mathrm{n}^{0}$ 7347. Isto se dá, salienta Grinover, porque os interesses que visa defender não são interesses públicos mas sim interesses privados de dimensão oletiva, nem a legitimação para agir nesse caso é restrita apenas a órgãos públicos.

7 Por falta de regulamentação quanto ao modo de aplicação dos recursos, o fundo paulista tem apenas recebido o dinheiro das indenizações, sem destiná-lo até agora a nenhuma atividade reparadora de danos causados.

8 Embora integrantes da instituição e juristas especializados no assunto afirmem que quase $90 \%$ das ACPs em tramitação na Justiça seja de autoria do Ministério Público, o fato é que não há dados estatísticos precisos a esse respeito. Algumas razões da aparente predominância do MP em relação aos demais agentes legitimados pela Lei $\mathrm{n}^{0} 7347$ podem ser aventadas: (1) comparativamente, 0 MP tem muito mais experiência de acusação perante 0 Judiciário (criminal, desde a sua origem, e agora também nas questões coletivas); (2) 0 MP, por ser órgão estatal, tem poder de requisitar documentos e informações para formar opinião sobre 0 problema, enquanto as associações civis não têm; (3) com a possibilidade de instaurar 0 inquérito civil, o MP pode preparar o terreno para a propositura da ação civil pública de modo muito mais eficaz do que as associações civis ou os demais órgãos públicos. Muitas vezes, o Ministério Público soluciona problemas já na fase do inquérito civil, dispensando o recurso à ação judicial. Por essas razões, é mais racional para as associações civis provocar o MP através de representações do que ingressar diretamente com medidas judiciais.

9 A questão da responsabilidade objetiva voltou ao debate público com a promulgação recente da Lei $\mathrm{n}^{0} 9605$ (de 12/2/ 1998), que ficou conhecida como a Lei dos Crimes Ambientais. Destinada a estabelecer "sanções penais e administrativas derivadas de condutas e atividades lesivas ao meio ambiente", seu processo de tramitação no Congresso deu oportunidade a setores descontentes com 0 princípio da responsabilidade objetiva, notadamente a bancada ruralista, de pedirem pela sua suspensão. Ao final, com os vetos presidenciais ao projeto de lei aprovado, o princípio da responsabilidade objetiva foi mantido para o caso das sanções decorrentes das ações civis públicas.

$10 \mathrm{Na}$ verdade, o projeto de lei aprovado no Congresso em 1985 era mais amplo, pois, além de mencionar expressamente tais interesses no art. 1, acrescentava através do inciso IV o dispositivo genérico de proteção "a qualquer outro interesse difuso ou coletivo". Entretanto, dado seu sentido indeterminado, este inciso foi vetado pelo então presidente da República. A esse respeito diz Mancuso (1994, pp. 29-30): "Com o veto presidencial, ficaram desprovidos de tutela [...] alguns relevantíssimos interesses difusos porque não abrangidos na órbita daqueles expressamente previstos (consumidores, meio ambiente, patrimônio cultural): a defesa do contribuinte (hoje mais do que nunca espoliado pela sanha fiscal insaciável); os participantes de programas habitacionais de massa, como os mutuários do $\mathrm{SFH}$; as minorias étnicosociais (cujos direitos fundamentais são imanentes à própria pessoa humana, mas que no entanto são marginalizadas, quando não perseguidas pela maioria conservadora e segregacionista); os pequenos acionistas e investidores modestos em sistemas populares de captação de poupança, e, bem assim, as pessoas lesadas por grandes conglomerados financeiros ou pelas ditas 'financeiras' etc."

11 Diz 0 art. 117 do Código: "Acrescente-se à Lei 7347 de 24 de setembro de 1985 o seguinte dispositivo, reenumerando 0 seguinte: "Art. 21 - Aplica-se à defesa dos direitos e interesses difusos, coletivos e individuais, no que for cabível, os dispositivos do título III da Lei que instituiu o Código de Defesa do Consumidor." O título III da Lei do CDC trata justamente dos aspectos processuais (da definição dos interesses, passando pela legitimação até os efeitos da coisa julgada, entre outros) relacionados à ação civil pública. Nesse sentido, 0 Código do Consumidor renova, reestrutura e explicita vários pontos da Lei $\mathrm{n}^{0} 7347 / 85$.

12 Os exemplos constantes do Quadro 1 foram retirados de Mazzilli (1994, pp. 21-23).

13 Ver nota 6.

14 Sobre esses princípios e a própria organização da atividade judicial ver Luhmann (1980).

15 Essa definição preliminar de "judicialização da política" (e seus desdobramentos ao longo do texto) é distinta daquela formulada por Castro (1997). Na parte do conceito que se refere aos órgãos de justiça formais (a segunda parte se refere a outros agentes), Castro localiza 0 fenômeno da judicialização da política em "um novo 'ativismo judicial', isto é, uma nova disposição de tribunais judiciais no sentido de expandir o escopo das questões sobre as quais eles devem formar juízos jurisprudenciais (muitas dessas questões até recentemente ficavam reservadas ao tratamento dado pelo Legislativo ou pelo Executivo)" (Castro, 1997, p. 148; 
grifos meus). Sem desconsiderar a importância da dimensão ativismo/ disposicão (ela é fundamental no caso do MP, como demonstrarei a seguir), penso que uma formulação adequada do conceito de judicialização da política requer, antes de mais nada, uma descrição do quadro institucional e das regras que permitem ou impedem ações tipicamente políticas por parte dos tribunais. Especialmente no que se refere ao Judiciário, poder inerte por definição, é necessário explicitar de que maneira sua atuação pode interferir no processo político stricto sensu (os mecanismos de controle constitucional das leis, por exemplo). A partir daí é que 0 ativismo judicial, se houver, e também a judicialização da política podem ser compreendidos.

16 Legitimidade extraordinária no sentido jurídico, ou seja, "a possibilidade de alguém, em nome próprio, defender interesse alheio". Cf. Mazzilli (1994, p. 25; grifo do autor).

17 Diz um dos promotores entrevistados sobre as razões desse problema: "Eu acho que tem uma tradição aí muito liberal, e também tem os outros aspectos que informam a vida coletiva: há injunções políticas, há injunções de natureza histórica, então há aí um inconsciente coletivo no Judiciário ainda muito liberal. Então, um levantamento jurisprudencial dessas questões é trágico, é trágico porque, para cada um desses casos de sucesso, você tem inúmeros outros em outras áreas também de insucesso, por deficiência do campo de luta; não dá pra se brigar com armas iguais, as coletividades são sempre prejudicadas pelas individualidades, então 0 dano social que isso tem trazido pra nós eu acho que é imenso. Talvez isso explique a ausência de outros atores nas ações civis que não uma instituição do próprio Estado, o que inicialmente poderia parecer um contrasenso." (Promotor 3).

18 Particularmente no nível federal, essa inversão deixou o Estado desamparado do ponto de vista da defesa judicial de seus interesses, tarefa antes desempenhada pelo Ministério Público Federal. Para solucionar o problema gerado pela separação entre Ministério Público e Poder Executivo, a Constituição de 1988 criou a Advocacia Geral da União, para representar o governo em ações na Justiça. A demora na definição complementar das atribuições do novo órgão, feita por lei apenas em 1993, impediu sua rápida organização e acarretou um volume extraordinário de derrotas judiciais para a União. Em meados de 1997, estimava-se 500 a 600 mil ações na Justiça brasileira contra a União. A Advocacia Geral da União contava então com 250 advogados. Já 0 Ministério Público herdou dessa separação uma estrutura material e de recursos humanos montada quando sua função principal era a defesa dos interesses do governo. Agora, toda a estrutura é colocada em movimento para defender a sociedade, tendo muito freqüentemente 0 poder público no banco dos réus.

19 As razões da escolha desse modelo de Ministério Público no processo constituinte de 1987-88 são analisadas por Nunes (1998).

20 Talvez a comparação mais sugestiva, por isso mesmo, não seja com os poderes políticos Executivo e Legislati- vo, mas com o Poder Judiciário, que mais se assemelha ao Ministério Público, em termos de origem e características institucionais. Nesse sentido, não podemos encontrar no Judiciário absolutamente nada de semelhante ao que vem ocorrendo com o MP nos últimos anos.

21 Cf. O Ministério Público e a Justiça no Brasil, Idesp, relatório de pesquisa, 1997. Desde 1993, o Instituto de Estudos Econômicos, Sociais e Políticos de São Paulo (Idesp) vem desenvolvendo um programa de pesquisa sobre as instituições judiciais brasileiras, particularmente em torno das causas do seu mau funcionamento e do enorme déficit de justiça que aflige 0 país. Como uma das etapas do programa, realizamos em 1996 um survey com integrantes do Ministério Público em sete estados brasileiros. Entrevistamos cerca de 20\% de promotores e procuradores de justiça do MP estadual em Goiás, Sergipe, Bahia, São Paulo, Rio de Janeiro, Paraná e Rio Grande do Sul, além de 51 integrantes do MP Federal distribuídos proporcionalmente por estes mesmos estados. No total, fizemos 763 entrevistas. 0 questionário utilizado nas entrevistas formulou, na primeira parte, questões sobre os aspectos mais evidentes da crise da Justiça, assim como as propostas de reforma mais destacadas no debate público. Na segunda parte, tratamos especialmente do papel do Ministério Público no âmbito do sistema de justiça e, em particular, dos limites e possibilidades de sua atuação na área dos direitos difusos e coletivos. Por último, um conjunto de questões substantivas sobre o Direito e a Justiça no Brasil procurou extrair dos entrevistados valores ideológicos e doutrinários que podem estar orientando sua atuação concreta.

22 Refiro-me ao survey realizado em 1993 pelo Idesp entre juízes de cinco estados brasileiros. Cf. A crise do Judiciário vista pelos juízes, Idesp, relatório de pesquisa, 1994. Para uma análise dos resultados ver Sadek e Arantes (1994).

23 É o que disse Hamilton, no artigo federalista 78: "O Judiciário, em contrapartida [com os demais poderes], não tem nenhuma influência nem sobre a espada nem sobre a bolsa; nenhum controle nem sobre a força nem sobre a riqueza da sociedade, e não pode tomar nenhuma resolução ativa. Pode-se dizer que não tem, estritamente, força nem vontade, mas tão-somente julgamento, estando em última instância na dependência do auxílio do braço executivo até para a eficácia de seus julgamentos." (Madison, 1993).

24 É sintomática, desse ponto de vista, a definição de cidadania que consta da Lei Orgânica do Ministério Público de São Paulo, quando, no artigo 295, que cria cargos especializados de promotor de justiça, dispõe sobre a função do promotor de justiça da Cidadania: "garantia de efetivo respeito dos poderes públicos e dos serviços de relevância pública aos direitos constitucionais assegurados nas Constituições federal e estaduais, da probidade e legalidade administrativas e da proteção do patrimônio público e social". Se o objetivo é defender os direitos do cidadão, a referência exclusiva aos poderes públicos e aos serviços de relevância pública 
nos indica que 0 concito de cidadania está referido ao Estado, ou melhor, em oposição a ele. Segundo essa definição, cabe ao MP enfrentar o Estado que, ao contrário do que deveria ser, tornou-se no Brasil um agente particular, não universal, enviesado nos seus propósitos, incapaz - nas poucas vezes em que está bem-intencionado - além de muitas vezes agir mesmo de má-fé. É contra o Estado que se deve dirigir a luta pelo respeito dos direitos constitucionais do cidadão e, através dele e de seus serviços públicos, ampliar efetivamente esses direitos, conclui 0 argumento.

25 Até pelo seu caráter especulativo, a análise precedente não teve a preocupação de remontar a história das idéias políticas no Brasil. Há inúmeros estudos nesse sentido e extensa é a historiografia que trata do pensamento antiliberal-democrático. No que diz respeito à natureza instrumental da solução apontada no discurso de integrantes do MP, um bom e já bastante conhecido quadro de referência é Santos (1978), no qual, apesar de algumas divergências centrais, busquei os termos para fazer a associação entre o MP e a tradição de crítica à fragilidade de nossa sociedade civil e de nossas instituições políticas.

26 A expressão é de Mancuso: "Na verdade, se essas instâncias ordinárias sempre operassem com a eficácia que é de se esperar, não temos dúvidas em afirmar que muito diminuiriam as ações civis públicas e as ações populares: é que o Judiciário é uma instância de substituição; ele atua quando provocado por um cidadão ou entidade que reclama quanto à inação ou má atuação do poder público, que deixa desprotegido ou ameaçado um interesse difuso relevante." (Mancuso, 1994; grifo meu).

27 Embora haja tradição de tutela judicial de direitos coletivos em outros países, como Alemanha, França, Inglaterra e principalmente Estados Unidos (as class actions), o fato é que a ação civil pública brasileira, apesar de se inspirar nessa experiência internacional, foi capaz de superá-la em vários aspectos: saiu do âmbito do consumidor e do meio ambiente (áreas que conferiram notoriedade inicial ao instrumento, tanto aqui como no exterior), atingindo uma série de conflitos de direito até o limite de incluir os direitos sociais que dificilmente são objeto de disputa judicial em outras democracias ocidentais, avançando também no que diz respeito à legitimação ativa e ao alcance jurídico dos efeitos das decisões judiciais em sede de ACP. Enfim, do ponto de vista do seu potencial de judicialização de conflitos, nada se compara à ação civil pública brasileira. Cf. Grinover (1984, pp. 78-84).

28 Lopes (1998) faz uma análise de casos judiciais iniciados por ação civil pública, particularmente na área de educação, e conclui que tais processos: (a) geralmente não são capazes de discutir os fundamentos constitucionais dos direitos sociais (somente os artigos da Constituição relativos à capacidade de agir do MP são invocados); (b) estão baseados comumente no Código de Defesa do Consumidor, o que limita 0 alcance da noção de direitos sociais como direitos públicos, não particularistas ou meramente contratuais; (c) em todos eles aparece o problema da legitimação extraordinária do MP e a dificuldade de consolidá-la perante os tribunais; (d) finalmente, em nenhum dos casos analisados pelo autor ele pôde encontrar qualquer referência aos aspectos distributivos de tais conflitos.

\section{BIBLIOGRAFIA}

AMARAL, Ana Lúcia. (1992), Processo civil coletivo: 0 acesso à Justiça no ano 2000. São Paulo, mimeo.

ARANTES, Rogério Bastos. (1997), Judicário e política no Brasil. São Paulo, Sumaré/ EDUC/ FAPESP.

CASTRO, Marcus Faro de. (1997), "O Supremo Tribunal Federal e a judicialização da política". Revista Brasileira de Ciências Sociais, Anpocs, 12, 34, junho.

FARIA, José Eduardo (org.). (1994), Direitos humanos, direitos sociais e Justica. São Paulo, Malheiros.

FERRAZ, Antonio A. Mello de Camargo (org.). (1997), Ministério Públioo: instituição e prooesso. São Paulo, Atlas.

GRINOVER, Ada Pellegrini (coord.). (1984), A tutela dos interesses difusos. São Paulo, Max Limonad.

LOPES, José Reinaldo L. (1998), "Social rights and the Courts", in T. Wilhelmsson (ed.), From dissonanoe to sense: privatisation and private law, Aldershot, Darmouth.

LUHMANN, Niklas. (1980), L egitimação pelo procedimento. Brasília, Ed. da UnB.

MACEDO JR, Ronaldo Porto. (1995), "A evolução institucional do Ministério Público Brasileiro", in M.T. Sadek (org.), Uma introdução ao estudo da Justiça, São Paulo/Rio de Janiero/ Nova York, Idesp/Ed. Sumaré/ Fundação Ford/ Fundação Mellon.

MACHADO, Antonio A. e GOULART, Marcelo P. (1992), Ministério Públioo e direito alternativo. São Paulo, Acadêmica.

MADISON, James et al. (1993), Os artigos federalistas, 1787-1788. Rio de Janeiro, Nova Fronteira. 
MANCUSO, Rodolfo de Camargo. (1994), A ção civil pública: em defesa do meio ambiente, patrimônio cultural e dos consumidores. Lei $7347 / 85$ e legislação complementar. $3^{\mathrm{a}}$ ed. revista e ampliada. São Paulo, Editora Revista dos Tribunais.

- (1997), Interesses difusos: conceitos e legitimação para agir. $4^{\mathrm{a}}$ ed. revista e atualizada. São Paulo, Editora Revista dos Tribunais.

MAZZILLI, Hugo Nigro. (1993), Regime jurídico do Ministério Públioo. São Paulo, Saraiva.

. (1994), A defesa dos interesses difusos em juízo. Meio ambiente, consumidor e outros interesses difusos e coletivos. $6^{\mathrm{a}}$ ed. revista, ampliada e atualizada. São Paulo, Editora Revista dos Tribunais.

NUNES, Fábio J. Kerche. (1998), 0 Ministério Públio e a Constituinte de 1987-88. Dissertação de mestrado, Universidade de São Paulo.

SADEK, Maria Tereza e ARANTES, Rogério Bastos. (1994), "A crise do Judiciário e a visão dos juízes". Revista USP, 21, mar.-maio, Dossiê Judiciário: 34-45.

SANTOS, Wanderley Guilherme dos. (1978), Ordem burguesa e liberalismo polítion. São Paulo, Duas Cidades. 